\title{
Innovation of Embedding Eggshell to Enhance Physical-Mechanical-Thermal Properties in Fired Clay Bricks via Extrusion Process
}

\author{
Nuchnapa Tangboriboon ${ }^{1, *}$, Sopita Moonsri ${ }^{1}$, Atima Netthip $^{1}$, and Anuvat Sirivat ${ }^{2}$ \\ ${ }^{1}$ Department of Materials Engineering, Faculty of Engineering, Kasetsart University ,Bangkok, \\ 10900, Thailand. \\ ${ }^{2}$ The Petroleum and Petrochemical College, Chulalongkorn University, Bangkok, 10330, Thailand.
}

\begin{abstract}
Eggshell functioned as a bio-filler and sintering aid added into earthenware clay compounds to make fire clay bricks via extrusion process. The main composition of eggshell is calcium carbonate $\left(\mathrm{CaCO}_{3}\right)$ while the main composition of earthenware is aluminosilcate $\left(\mathrm{Al}_{2} \mathrm{O}_{3} \cdot 2 \mathrm{SiO}_{2} \cdot 2 \mathrm{H}_{2} \mathrm{O}\right)$ and other oxide compounds. Calcium carbonate in eggshell can react to chemical substances in earthenware clay compound to form calcium alumnosilicate or anorthite and wollastonite or calcium silicate phase formation of the fired clay bricks. Adding $20 \%$ wt eggshell powder into clay bricks and fired at $1000^{\circ} \mathrm{C}$ for $5 \mathrm{hrs}$., affects to the physical-mechanical-thermal properties, i.e. high compressive strength and hardness, good thermal expansion coefficient, good true density, and low water absorption. In general, the theoretical compressive strength, hardness, and water absorption of desired refractory are more than 7.0 $\mathrm{MPa}, 6.0 \mathrm{HV}$, and less than $25 \% \mathrm{wt}$, respectively. Therefore, the obtained fired clay bricks added eggshell powder and fired at $1000^{\circ} \mathrm{C}$ for $5 \mathrm{hrs}$., are potential for use as bricks for construction and thermal insulation.
\end{abstract}

\section{Introduction}

Eggs have been used as foods, drugs, cosmetics, and foodstuffs. Unfortunately, eggshells are an egg product industry residue that contributes to environmental pollution as it favors microbial actions. The by-product eggshell represents approximately $11 \%$ of the total weight approximately $60 \mathrm{~g}$ of egg [1-2]. Eggshell is one kind of sources of calcium carbonate $\left(\mathrm{CaCO}_{3}\right)$ known as calcite which is the more stable polymorph at room temperature. An eggshell is a rich source of mineral salts, mainly calcium carbonate $(94 \%)$, calcium phosphate (1\%), magnesium carbonate (91\%), and organic substances (4\%) [2]. However, an important composition of eggshell is the calcium carbonate, which can be used in various material applications: dielectrics, dental and bone implantation, gypsum, catalysts, and also fillers used for in a variety industries such as rubber, ink, foodstuff, cosmetic, pharmaceutical, and fertilization.

Brick is a ceramic material mainly used in the building industry. There are divided into various groups on the basis of the mainly raw materials used, namely silica bricks, magnesia bricks, zirconia bricks, alumina bricks, mullite bricks, dolomite bricks, silicon carbide bricks, graphite bricks, and clay bricks [3-19]. Bricks are the major-construction and building material for a long time. The worldwide annual production of bricks is currently many thousand billion units and has trended the demand to increase every year. Conventional bricks are produced from clay and fired at high temperature. Earthenware is

\footnotetext{
* Corresponding author: fengnnpt@ku.ac.th
} 
one kind of clay raw materials to produce clay brick because earthenware is the lowest price of raw material used, high percentage of iron oxide content, red or yellow color after firing, opaque, high plasticity, easily forming. Earthenware can be fired for biscuit at $1000^{\circ}-1150^{\circ} \mathrm{C}$. The most application of earthenware are the building bricks in block shape or rectangular building unit. There are many sources of earthenware in the provinces of Thailand such as Udon Thani (Ban Chiang), Sukhothai (Si satchanalai), Sawankhalok, Ayutthaya, Lopburi, Singburi, Kanchanburi, and Angthong which are high potential to make the good and strong traditional clay-bricks.

The annual growth rate of clay bricks using for construction, infrastructure, and industries, i.e. furnace for steel and jewelry making, materials, casting process, and others, increase continuously demand effect of the high rate of brick production for building enclosures. However, both economic and environmental problems during process need to concern on energy consuming, pollution, cost of production, and raw material sources. Therefore, one of the best ways of saving energy consumption and reducing eggshell waste is applied eggshell as a $\mathrm{CaCO}_{3}$ filler and flux in clay bricks. In addition, recycled eggshell as a bio-filler can decrease the landfill pollution and contributes as an asset to the agriculture rather than being a waste material.

The objective of this work was to make fire clay bricks from earthenware clay mixed with eggshell $\left(\mathrm{CaCO}_{3}\right)$ powder. The obtained fired clay bricks which have good physical, mechanical, and thermal properties, lightweight, and low water absorption.

\section{Experimentals}

\subsection{Materials and methods}

Earthenware clay was obtained from Pa Mok district, Ban Norasing, Angthong province, Thailand. Hen eggshell was collected from the local cafeteria of the University. Eggshell was cleaned with tap water and let it dry in the air at room temperature for 1-2 days. The cleaned hen eggshell was ground with the rapidly porcelain ball mill to eggshell powder for $120 \mathrm{~min}$.

\subsection{Instruments}

Extruder was used to prepare clay brick samples supplied by Petkasem Co.,Ltd., Thailand. Extruder composed of a screw to extrude the clay mixture from the hopper to the die. Barrel in the extruder can protect the mixture flow out the screw and get rid of the air containing in the mixture. Oven was used to dry the green products at $100^{\circ} \mathrm{C}$ for $24 \mathrm{hrs}$ by using the WTB binder. Furnace was used to fire the clay bricks at $800^{\circ}, 900^{\circ}, 1000^{\circ}$, and $1100^{\circ} \mathrm{C}$ for 1,3 , and 5 hrs., at each firing temperature. The used furnace is Mudotemp, WW 51A model $1400^{\circ} \mathrm{C}$.

\subsection{Clay bricks preparation}

The green products of clay brick samples were prepared according to the Table 1 . The raw materials were mixed and kneaded to homogenous mixture and extrude pass through the die of extruder in a cylindrical shape having $5.00 \mathrm{~cm}$ diameter and $1.00 \mathrm{~cm}$ in thickness. The obtained clay samples or green products were dried at $100^{\circ} \mathrm{C}$ for $24 \mathrm{hrs}$, , and then fired at $800^{\circ}, 900^{\circ}, 1000^{\circ}$, and $1100^{\circ} \mathrm{C}$ for 1,3 , and $5 \mathrm{hrs}$., at each firing temperature, respectively. 
Table 1. Raw materials were mixed and needed to homogenous mixture and extrude pass

\begin{tabular}{|c|c|c|c|}
\hline Samples & $\begin{array}{c}\text { Earthenware clay } \\
(\mathbf{g})\end{array}$ & $\begin{array}{c}\text { Eggshell powder } \\
(\mathbf{\%} \mathbf{w t})\end{array}$ & $\begin{array}{c}\text { Water } \\
(\mathbf{\%} \text { wt) }\end{array}$ \\
\hline Formula 1 & 12,000 & 0 & 40 \\
\hline Formula 2 & 11,400 & 5 & 40 \\
\hline Formula 3 & 10,800 & 10 & 40 \\
\hline Formula 4 & 10,200 & 15 & 40 \\
\hline Formula 5 & 9,600 & 20 & 40 \\
\hline
\end{tabular}

\section{Results and discussion}

\subsection{Physical properties of clay bricks}

The color of green products means the color of samples before firing as shown in Fig.1.
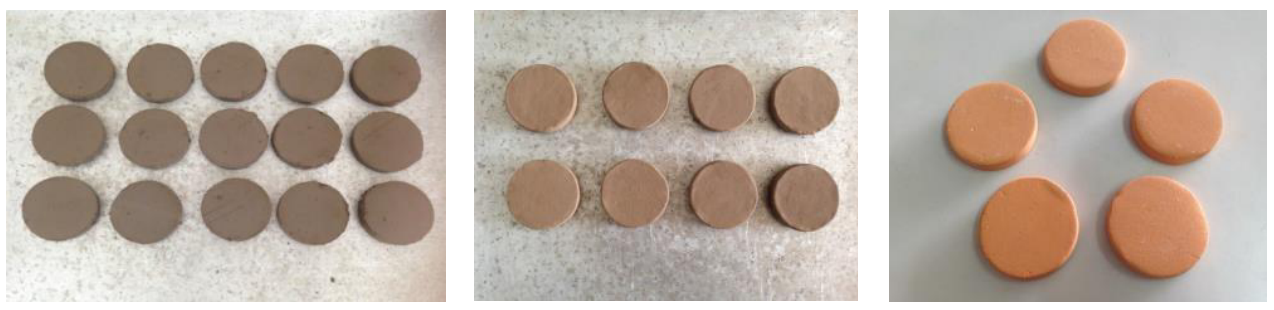

Fig. 1. Clay brick samples: a) the green products before drying; b) the green products after drying in an oven at $100^{\circ} \mathrm{C}$ for $24 \mathrm{hrs}$.; and c) the clay bricks after firing at $800^{\circ}-1100^{\circ} \mathrm{C}$.

Most color of clay bricks before firing or green products after kneading and extrusion are dark yellowish brown. After firing, the colors of clay bricks are reddish yellow to pale yellow.

The chemical composition of clay and chicken eggshell for clay refractory forming was measured by XRF as the data tabulated in Table2. The main composition of earthenware clay composed of $26.46 \%$ wt $\mathrm{SiO}_{2}, 22.32 \%$ wt $\mathrm{Fe}_{2} \mathrm{O}_{3}, 20.66 \%$ wt $\mathrm{Al}_{2} \mathrm{O}_{3}$, and other oxide compounds. While the main composition of chicken eggshell composed of $98.101 \% \mathrm{wt}$ $\mathrm{CaCO}_{3}$ and the rest other oxide compounds. 
Table 2. Chemical composition by XRF

\begin{tabular}{|c|c|c|}
\hline Composition & $\begin{array}{c}\text { Earthenware clay } \\
(\% \text { wt })\end{array}$ & $\begin{array}{c}\text { Hen eggshell } \\
\text { (\%)wt) }\end{array}$ \\
\hline $\mathrm{SiO}_{2}$ & 26.46 & 0.073 \\
\hline $\mathrm{Fe}_{2} \mathrm{O}_{3}$ & 22.32 & - \\
\hline $\mathrm{Al}_{2} \mathrm{O}_{3}$ & 20.66 & 0.035 \\
\hline $\mathrm{CaO}$ & 10.55 & - \\
\hline $\mathrm{MgO}$ & 8.91 & 0.286 \\
\hline $\mathrm{Na}_{2} \mathrm{O}$ & 4.43 & 0.204 \\
\hline $\mathrm{K}_{2} \mathrm{O}$ & 4.39 & 0.038 \\
\hline $\mathrm{TiO}_{2}$ & 2.28 & - \\
\hline $\mathrm{CaCO}_{3}$ & - & 98.101 \\
\hline $\mathrm{CuO}_{2}$ & - & 0.009 \\
\hline $\mathrm{P}_{2} \mathrm{O}_{5}$ & - & 0.443 \\
\hline $\mathrm{SrO}_{\mathrm{SO}}$ & - & 0.013 \\
\hline $\mathrm{SO}_{3}$ & - & 0.798 \\
\hline $\mathrm{Total}$ & 100.00 & 100.00 \\
\hline
\end{tabular}

"_" means not detected.

The physical properties (bulk density, true density, color, and water absorption) of clay brick samples added $0 \%, 5 \%, 10 \%, 15 \%$, and $20 \%$ wt chicken eggshell powder fired at $800^{\circ} \mathrm{C}, 900^{\circ} \mathrm{C}, 1000^{\circ} \mathrm{C}$, and $1100^{\circ} \mathrm{C}$ for 1,3 , and $5 \mathrm{hrs}$, , are data tabulated in Table 3. Firing temperature and firing time are important factors to obtain the good clay bricks. The high firing temperature and firing time use, the better and higher strength of clay bricks obtained. The firing temperature is low less than $1000^{\circ} \mathrm{C}\left(800^{\circ} \mathrm{C}\right.$ and $\left.900^{\circ} \mathrm{C}\right)$, the samples are not good and low strength. However, if the firing temperature is too high more than $1000^{\circ} \mathrm{C}$ effect to crack on clay brick samples. Therefore, the suitable firing temperature of clay brick samples added eggshell powder is $1000^{\circ} \mathrm{C}$ for firing time 1,3 , and $5 \mathrm{hrs}$. Furthermore, if the percentage of chicken eggshell powder added in the clay bricks is high, the percentage value of water absorption is low and good appearance. The obtained clay brick samples added $20 \%$ wt eggshell powder are the optimum amount of hen eggshell adding. The average water absorption of adding $20 \%$ wt eggshell is equal to $14.36-14.88 \%$ consistent with the results obtained by Raut et al [9]. It means high densification effect to samples having high mechanical and good thermal properties. Furthermore, the obtained water absorption of clay brick samples has low values consistent with the theoretical values of the best refractory measured according to the Thai Industrial Standard Institute 243/2530 and the ASTM C 373-72 less than 25\%wt water absorption. 
Table 3. Physical properties of brick samples

\begin{tabular}{|c|c|c|c|c|}
\hline Samples $^{a}$ & $\begin{array}{c}\text { Bulk density } \\
\left(\mathrm{g} / \mathrm{cm}^{3}\right)\end{array}$ & $\begin{array}{c}\text { True density }^{\mathrm{c}} \\
\left(\mathrm{g} / \mathrm{cm}^{3}\right)\end{array}$ & $\begin{array}{c}\text { Water absorption }{ }^{\mathrm{d}} \\
\text { (\% wt) }\end{array}$ & Color of bricks \\
\hline $0-1000-1$ & $1.80 \pm 0.04$ & $2.05 \pm 0.01$ & $16.69 \pm 0.04$ & Red yellow \\
\hline $0-1000-3$ & $1.83 \pm 0.01$ & $2.07 \pm 0.02$ & $15.79 \pm 0.66$ & Red yellow \\
\hline $0-1000-5$ & $1.83 \pm 0.03$ & $2.12 \pm 0.07$ & $15.37 \pm 1.28$ & Red yellow \\
\hline $5-1000-1$ & $1.71 \pm 0.03$ & $1.97 \pm 0.05$ & N/A & Red yellow \\
\hline $5-1000-3$ & $1.73 \pm 0.03$ & $2.01 \pm 0.05$ & N/A & Red yellow \\
\hline $5-1000-5$ & $1.75 \pm 0.01$ & $2.05 \pm 0.02$ & N/A & Red yellow \\
\hline $10-1000-1$ & $1.69 \pm 0.02$ & $2.03 \pm 0.03$ & N/A & Red yellow \\
\hline $10-1000-3$ & $1.67 \pm 0.01$ & $2.02 \pm 0.03$ & N/A & Red yellow \\
\hline $10-1000-5$ & $1.70 \pm 0.02$ & $2.04 \pm 0.05$ & N/A & Red yellow \\
\hline $15-1000-1$ & $1.63 \pm 0.02$ & $1.97 \pm 0.01$ & N/A & Red yellow \\
\hline $15-1000-3$ & $1.65 \pm 0.02$ & $1.99 \pm 0.01$ & N/A & Red yellow \\
\hline $15-1000-5$ & $1.64 \pm 0.03$ & $2.00 \pm 0.02$ & N/A & Red yellow \\
\hline $20-1000-1$ & $1.83 \pm 0.01$ & $2.06 \pm 0.08$ & $14.88 \pm 0.89$ & Yellow \\
\hline $20-1000-3$ & $1.70 \pm 0.02$ & $1.98 \pm 0.02$ & $14.69 \pm 1.04$ & Yellow \\
\hline $20-1000-5$ & $1.75 \pm 0.04$ & $1.96 \pm 0.02$ & $14.36 \pm 0.80$ & Yellow \\
\hline
\end{tabular}

Remark: N/A means not measured.

${ }^{a}$ means 5 pieces of clay brick samples at each condition.

${ }^{b}$ means density including open and closed pores within the clay samples according to the ASTM B212-82.

${ }^{\mathrm{c}}$ means density without open and closed pores within the clay samples due to boiled in water for 5 hrs., and let them in cool water for 24 hrs., before calculation according the ASTM B212-72 and ASTM C 373-72.

${ }^{\mathrm{d}}$ means water absorption according to the ASTM C 373-72.

Encoded samples $\mathrm{x}$-xxxx-x mean amount of eggshell powder adding-firing temperature-firing time i.e. $0-1000-3$ (no adding ( $0 \% \mathrm{wt}$ ) eggshell powder -firing at $1000^{\circ} \mathrm{C}$-firing time for $3 \mathrm{hrs}$ ).

When the clay bricks were mixed with the eggshell powder $0 \%, 5 \%, 10 \%, 15 \%$, and $20 \%$ wt effect on the color of mixture changed according to the Munsell soil color chart from dark yellowish brown to very pale yellow as reported in Table 4 . The clay brick samples were prepared by extrusion in a disk-like shape, having $5.00 \mathrm{~cm}$ diameter and 1.00 $\mathrm{cm}$ thickness. All clay brick samples were fired at $800^{\circ} \mathrm{C}, 900^{\circ} \mathrm{C}, 1000^{\circ} \mathrm{C}$, and $1100^{\circ} \mathrm{C}$ for 1,3 , and $5 \mathrm{hrs}$., at each firing temperature. The colors of clay brick samples changed to reddish yellow or yellow as reported in Table 4 due to the amount of iron oxide $\left(\mathrm{Fe}_{2} \mathrm{O}_{3}\right)$ having red color consistent with the results obtained by XRF and amount of hen eggshell powder adding.

The XRD peak patterns comparison of raw materials (earthenware clay and hen eggshell powder) and clay brick samples added $0 \%$ and $20 \%$ wt hen eggshell powder fired at $1000^{\circ} \mathrm{C}$ for 1,3 , and $5 \mathrm{hrs}$., are shown in Fig. 2. The XRD peak patterns of earthenware clay at $2 \Theta\left(26.832^{\circ}, 50.079^{\circ}\right.$, and $\left.60.026^{\circ}\right)$ consistent with the JCPDS nos. 01-089-8936 (quartz), 00-003-0447 (aluminum phosphate), and 00-019-0615 (iron oxide, $\mathrm{Fe}_{2} \mathrm{O}_{3}$ ) are hexagonal phase formation of $\mathrm{SiO}_{2}-\mathrm{Al}_{2} \mathrm{O}_{3}-\mathrm{Fe}_{2} \mathrm{O}_{3}$. While the XRD peak patterns of chicken eggshell powder show rhombohedral of calcium carbonate $\left(\mathrm{CaCO}_{3}\right)$ or calcite consistent with the JCPDS nos. $01-072-1937$ at $2 \Theta\left(29.369^{\circ}, 48.452^{\circ}, 47.450^{\circ}, 39.370^{\circ}\right.$, and $\left.43.118^{\circ}\right)$. The XRD peak patterns of fired clay brick without adding eggshell powder and fired at $1000^{\circ} \mathrm{C}$ for 1,3 , and $5 \mathrm{hrs}$., are shown only hexagonal crystalline phase formation of $\mathrm{SiO}_{2}-$ $\mathrm{Al}_{2} \mathrm{O}_{3}-\mathrm{Fe}_{2} \mathrm{O}_{3}$ consistent with the JCPDS nos. 01-089-8936 (quartz, $\mathrm{SiO}_{2}$ ), 00-049-0134 (aluminum oxide, $\mathrm{Al}_{2} \mathrm{O}_{3}$ ), and 00-019-0615 (iron oxide, $\mathrm{Fe}_{2} \mathrm{O}_{3}$ ). The XRD peak patterns of fired clay brick samples added $20 \%$ wt eggshell powder and fired at $1000^{\circ} \mathrm{C}$ show sharp two peaks of anorthic phase formation of JCPDS nos. 00-003-0559 calcium aluminum silicate $\left(\mathrm{CaAl}_{2} \mathrm{Si}_{2} \mathrm{O}_{8}\right.$ or calcium feldspar) and calcium silicate $\left(\mathrm{CaSiO}_{3}\right.$ or wollastonite $)$ at $2 \Theta$ 
$\left(26.881^{\circ}-28.776^{\circ}, 23.205^{\circ}, 36.650^{\circ}\right.$, and $\left.43.473^{\circ}\right)$ mixed with the cubic phase formation of calcium oxide $(\mathrm{CaO})$ of JCPDS no. $00-048-1467$ at $2 \Theta\left(37.360^{\circ}, 53.860^{\circ}\right.$, and $\left.32.200^{\circ}\right)$ and consistent with the results reported by Gökhan, G. et al. [13], Cultrone, G., et al. [15], Jordan, M.M et al.[20], Xia, W., et al. [21], and Wan, X. et al. [22]. Furthermore, the XRD peak patterns of fired clay bricks added $20 \%$ wt eggshell powder and fired at $1000^{\circ} \mathrm{C}$ show hexagonal phase formation of $\mathrm{SiO}_{2}-\mathrm{Al}_{2} \mathrm{O}_{3}-\mathrm{Fe}_{2} \mathrm{O}_{3}$ consistent with JCPDS nos. 01-089-8936, 00-049-0134, and 00-019-0615. The sharp XRD peak at $2 \Theta 28.776^{\circ}$ belongs to calcium aluminum silicate $\left(\mathrm{CaAl}_{2} \mathrm{Si}_{2} \mathrm{O}_{8}\right.$ or calcium feldspar) occurring obviously when the clay bricks were fired at $1000^{\circ} \mathrm{C}$ for 5 hrs., consistent with the results obtained by Jordan, M.M. et al. [20]. It means completely vitreous firing effect of high mechanical and good thermal properties of products.

Table 4. Color of clay brick before and after firing

\begin{tabular}{|c|c|c|}
\hline $\begin{array}{c}\text { Encoded samples } \\
\text { (\% wt eggshell-firing temperature) }\end{array}$ & $\begin{array}{l}\text { Color of samples after firing } \\
\text { (Munsell soil color chart) }\end{array}$ & $\begin{array}{l}\text { Color of samples } \\
\text { after firing }\end{array}$ \\
\hline $0 \%$ wt-before firing & $10 \mathrm{YR} 5 / 6$ & dark yellowish brown \\
\hline $5 \%$ wt-before firing & 10YR5/6 & yellowish brown \\
\hline $10 \%$ wt-before firing & 10YR7/4 & very pale brown \\
\hline $15 \% \mathrm{wt}-b e f o r e$ firing & $10 \mathrm{YR} 7 / 4$ & very pale brown \\
\hline $20 \% \mathrm{wt}-$ before firing & 10YR7/4 & very pale brown \\
\hline $0 \% \mathrm{wt}-800^{\circ} \mathrm{C}$ & 7.5 YR7/8 & reddish yellow \\
\hline $0 \%$ wt $-900{ }^{\circ} \mathrm{C}$ & 7.5 YR7/8 & reddish yellow \\
\hline $0 \%$ wt $-1000^{\circ} \mathrm{C}$ & 7.5YR7/8 & reddish yellow \\
\hline $0 \%$ wt $-1100^{\circ} \mathrm{C}$ & 7.5YR7/8 & reddish yellow \\
\hline $5 \%$ wt $-800{ }^{\circ} \mathrm{C}$ & $7.5 \mathrm{YR} 7 / 6$ & reddish yellow \\
\hline $5 \%$ wt $-900{ }^{\circ} \mathrm{C}$ & $7.5 \mathrm{YR} 7 / 6$ & reddish yellow \\
\hline $5 \%$ wt $-1000{ }^{\circ} \mathrm{C}$ & $7.5 \mathrm{YR} 7 / 6$ & reddish yellow \\
\hline $5 \%$ wt $-1100^{\circ} \mathrm{C}$ & $7.5 \mathrm{YR} 7 / 6$ & reddish yellow \\
\hline $10 \%$ wt $-800^{\circ} \mathrm{C}$ & $7.5 \mathrm{YR} 7 / 6$ & reddish yellow \\
\hline $10 \%$ wt $-900{ }^{\circ} \mathrm{C}$ & 7.5 YR7/6 & reddish yellow \\
\hline $10 \%$ wt $-1000{ }^{\circ} \mathrm{C}$ & $7.5 \mathrm{YR} 7 / 6$ & reddish yellow \\
\hline $10 \%$ wt $-1100^{\circ} \mathrm{C}$ & $7.5 \mathrm{YR} 7 / 6$ & reddish yellow \\
\hline $15 \% w t-800^{\circ} \mathrm{C}$ & 7.5 YR7/6 & reddish yellow \\
\hline $15 \% w t-900^{\circ} \mathrm{C}$ & 7.5 YR7/6 & reddish yellow \\
\hline $15 \%$ wt $-1000^{\circ} \mathrm{C}$ & $7.5 \mathrm{YR} 7 / 6$ & reddish yellow \\
\hline $15 \%$ wt $-1100{ }^{\circ} \mathrm{C}$ & $7.5 \mathrm{YR} 7 / 6$ & reddish yellow \\
\hline $20 \%$ wt $-800^{\circ} \mathrm{C}$ & $10 \mathrm{YR} 8 / 6$ & Yellow \\
\hline $20 \%$ wt $-900^{\circ} \mathrm{C}$ & $10 \mathrm{YR} 8 / 6$ & Yellow \\
\hline $20 \%$ wt $-1000^{\circ} \mathrm{C}$ & $10 \mathrm{YR} 8 / 6$ & Yellow \\
\hline $20 \% \mathrm{wt}-1100^{\circ} \mathrm{C}$ & $10 \mathrm{YR} 8 / 6$ & Yellow \\
\hline
\end{tabular}

The mechanical properties (compressive strength and hardness) of clay bricks are measured according to the Thai Industrial Standard Institute 243/2520. The data comparison of clay brick samples with and without $0 \%, 5 \%, 10 \%, 15 \%$, and $20 \% \mathrm{wt}$ eggshell powder fired at $1000^{\circ} \mathrm{C}$ for 1,3 , and 5 hrs., at each firing temperature are shown in Table 5. The high percentage of amount eggshell powder added in clay bricks, the better and higher compressive strength and hardness values of clay bricks are. The best condition of samples firing and eggshell adding to get the highest compressive strength and hardness clay brick is $20 \%$ wt eggshell powder adding and firing at $1000^{\circ} \mathrm{C}$ for $5 \mathrm{hrs}$., namely sample 20-1000-5. The compressive strength and hardness values of the best condition (20-1000-5) are $8.28 \mathrm{MPa}$ and $8.79 \pm 0.60 \mathrm{HV}$, respectively. While the clay brick sample without adding eggshell powder fired $1000^{\circ} \mathrm{C}$ for $5 \mathrm{hrs}$, has the compressive strength $7.42 \mathrm{MPa}$ and 
hardness $7.63 \pm 0.30 \mathrm{HV}$, respectively. The theoretical compressive strength and hardness values of the best fired clay brick according to the Thai Industrial Standard Institute 243/2530 and the ASTM C 373-72 should have the data more than 7.0 MPa and 6.0 HV, respectively.

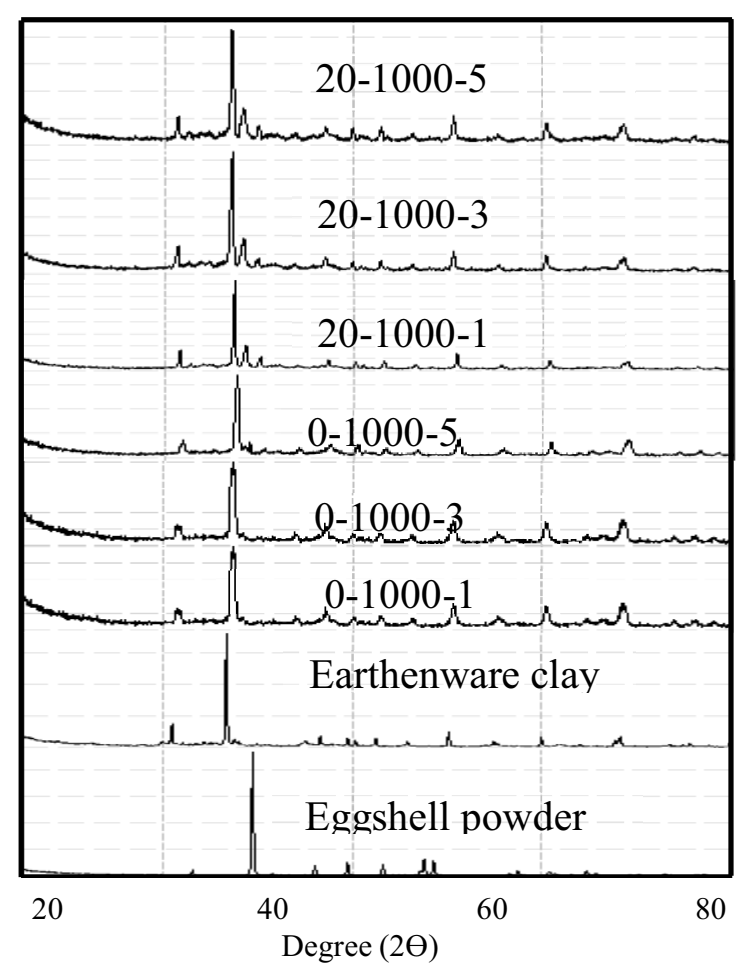

Fig. 2. The XRD peak patterns of samples: eggshell powder, earthenware clay, and tired clay bricks added 0 and $20 \%$ wt eggshell powder after firing at $1000^{\circ} \mathrm{C}$ for 1,3 , and $5 \mathrm{hrs}$., respectively.

The thermal expansion coefficient is one kind of the thermal properties of materials. The obtained fired clay bricks added eggshell powder and fired at $1000^{\circ} \mathrm{C}$ for $3 \mathrm{hrs}$., or 5 hrs., have low thermal expansion coefficient value less than those of fired clay bricks without adding eggshell powder at the same firing temperature and firing time. It means adding eggshell in fired clay bricks better than samples without eggshell adding. Thermal expansion coefficient values of clay bricks added eggshell powder and fired at $1000^{\circ} \mathrm{C}$ for 3 and $5 \mathrm{hrs}$., are $3.2605 \times 10^{-6}$ and $2.3652 \times 10^{-6}\left({ }^{\circ} \mathrm{C}\right)^{-1}$. While thermal expansion coefficient values of fired clay bricks without adding eggshell powder and fired at $1000^{\circ} \mathrm{C}$ for 3 and 5 hrs., are $4.7846 \times 10^{-6}$ and $3.6566 \times 10^{-6}\left({ }^{\circ} \mathrm{C}\right)^{-1}$. The low thermal expansion coefficient of materials has, the better thermal shock resistance is. Therefore, the fired clay brick sample added $20 \%$ wt eggshell powder and fired at $1000^{\circ} \mathrm{C}$ for $5 \mathrm{hrs}$., is the best condition to receive the good physical, mechanical and thermal properties. 
Table 5. Mechanical properties of clay bricks

\begin{tabular}{|c|c|c|}
\hline Samples* $^{*}$ & Compressive strength (MPa) & Hardness (HV) \\
\hline $0-1000-1$ & 7.05 & $7.27 \pm 0.20$ \\
$20-1000-1$ & 8.09 & $8.38 \pm 0.87$ \\
\hline $0-1000-3$ & 7.37 & $7.47 \pm 0.60$ \\
$20-1000-3$ & 8.18 & $8.55 \pm 0.10$ \\
\hline $0-1000-5$ & 7.42 & $7.63 \pm 0.30$ \\
$20-1000-5$ & 8.28 & $8.79 \pm 0.60$ \\
\hline
\end{tabular}

Table 6. Thermal expansion coefficient of clay bricks

\begin{tabular}{|c|c|}
\hline Samples $^{\mathbf{a}}$ & Thermal expansion coefficient $^{\mathbf{b}}\left({ }^{\circ} \mathbf{C}^{-\mathbf{1}}\right.$ \\
\hline $0-1000-3$ & $4.7846 \times 10^{-6}$ \\
\hline $0-1000-5$ & $3.6566 \times 10^{-6}$ \\
\hline $20-1000-3$ & $3.2605 \times 10^{-6}$ \\
\hline $20-1000-5^{* *}$ & $2.3652 \times 10^{-6}$ \\
\hline
\end{tabular}

Remark:

*Encoded of samples $\mathrm{x}$-xxxx-x mean amount of eggshell powder adding-firing temperature-firing time i.e. 0 1000-3 (no adding $(0 \% \mathrm{wt})$ eggshell powder -firing at $1000^{\circ} \mathrm{C}$-firing time for $3 \mathrm{hrs}$.).

** means the best condition due to the low thermal expansion coefficient effect to good thermal shock resistance.

\section{Conclusions}

Adding chicken eggshell powder into clay bricks can increase physical-mechanical-thermal properties of products. The higher amount of adding eggshell powder into clay bricks is, the better physical-mechanical-thermal properties of clay bricks are due to calcium oxide content caused to calcium feldspar, calcium silicate, and wollastonite phase formation. The firing temperature and soaking time is an important factors affect to densification or vitrification due to low porosity and completion of the glassy phase formation. The best condition of fired clay bio-bricks are firing at $1000^{\circ} \mathrm{C}$ for $5 \mathrm{hrs}$. The fired clay bio-bricks added $20 \%$ wt eggshell powder and fired at $1000^{\circ} \mathrm{C}$ for $5 \mathrm{hrs}$., are high compressive strength and hardness $(8.28 \mathrm{MPa}$ and $8.79 \pm 0.60 \mathrm{HV})$, good thermal expansion coefficient $2.3652 \mathrm{x}$ $10^{-6}\left({ }^{\circ} \mathrm{C}\right)^{-1}$, good true density $1.96 \pm 0.02 \mathrm{~g} / \mathrm{cm}^{3}$, and low water absorption $14.36 \pm$ $0.80 \%$ wt. The theoretical compressive strength, hardness, and water absorption values of fired refractory according to the Thai Industrial Standard Institute 243/2530 and the ASTM C 373-72 should have the values more than 7.0 MPa, 6.0 HV, and less than $25 \% \mathrm{wt}$, respectively. Therefore, the obtained fired clay bio-bricks added $20 \%$ wt eggshell powder and fired at $1000^{\circ} \mathrm{C}$ for $5 \mathrm{hrs}$., are potential to use as clay bricks for construction and thermal insulation.

The authors would like to thank the following: The Petroleum and Petrochemical College, and the Scientific and Technological Research Equipment Centre, at Chulalongkorn University, Thailand; the Department of Materials Engineering, at Kasetsart University for the use of their analytical equipment. We are grateful for the grant support from Agricultural Research Development Agency (Public Organization) or ARDA of Ministry of Agricultural and Cooperatives encoded PRP5605010080 of the fiscal year 2013-2014. We are also grateful for the grant support from Center for Advanced Studies in Industrial Technology and the Kasetsart University Research and Development of the fiscal year 2014. We also would like to acknowledge the financial support from Conductive and Electroactive Polymers Research Unit of Chulalongkorn University, the Thailand Research Fund (TRF-BRG), and the Royal Thai Government. 


\section{References}

1. W.T. Tsai, J.M. Yang, C.W. Lai, Y.H. Cheng, C.C. Lin, C.W. Yeh, Bioresour. Technol., 97, 488 (2006)

2. Y. Nys, J. Gautron, J.M. Garcia Ruiz, M.T. Hincke, C.R. Palevol., 3, 549 (2004)

3. S. Ahmad, Y. Iqbal, F. Ghani, J. Pak. Mater. Soc., 1(2), 33 (2008)

4. L. Zhang. Constr. Build Mater., 47, 633 (2013)

5. F.F. Singer, Industrial ceramics (Chapman Hall, London, 1979)

6. F. Karim, Ceramics \& Plastics: Testing of Engineering (Ferozsons, Lahore, 1998)

7. J.B. Weems, Iowa Geological Survey Annual Report, 14, 319 (1903)

8. Technical Notes on Brick construction (Brick Industry Association, 2006)

9. S.P. Raut, R.V. Ralegaonkar, S.A. Constr. Build Mater., 25(10), 4037 (2011)

10. I. Johari, S. Said, B. Hisham, A. Bakar, Z.A. Ahmad, Sci. Sinter., 42, 245 (2010)

11. M. Sutcu, S. Akkurt, Ceram. Int., 35(7), 2065 (2009)

12. A. Ukwatta, A. Mohajerani, S. Setunge, N. Eshtiaghi, Constr. Build Mater., 91, 86 (2015)

13. G. Gorhan, O. Şimşek, Constr. Build Mater., 40, 390 (2013)

14. F. Kristaly, I. Kocserha, Mater. Sci. Forum, 659, 43 (2010)

15. G. Cultrone, C. Rodriguez-Navarro, E. Sebastian, O. Cazalla, M.J. Delatorre, Eur. J. Mineral, 31, 621 (2001)

16. EN 832: Thermal Performance of Building Calculation of Energy Use for Heating Residential Buildings, (CEN, Brussels, Belgium, 1998)

17. D.A. Oliveira, P. Benelli, E.R. Amante, J. Clean. Prod., 46, 42 (2013)

18. F.S. Murakami, P.O. Rodrigues, C.M.T. Campos, M.A.S. Silva, Cienc. Tecnol. Aliment., 27(3), 658 (2007)

19. M.J. Trindade, M.I. Dias, F. Coroado-Rocha, Appl. Clay. Sci., 42(3), 345 (2009)

20. M.M. Jordan, T. Sanfeliu, C. de la Fuente, Appl. Clay. Sci., 20, 87 (2001)

21. W. Xia, J. Chang, Micropor. Mesopor. Mat., 108(1-3), 345 (2008)

22. X. Wan, C. Chang, D. Mao, L. Jiang, M. Li, Mater. Sci. Eng. C, 25, 455 (2005) 